\title{
Pedagogical Use of Laptops in a One-to-One Environment in a Swedish Primary School
}

\author{
Ann-Louise Petersen \& Leona Bunting \\ University West, Sweden
}

\begin{abstract}
This article focuses on computing in teaching. It focuses on the differences between a traditional view of teaching and a view where the teacher no longer is the knowledge broker but more of a coordinator or a coach. The empirical examples stem from a research project called "One computer one pupil", a study of two classes in year three with children aged 9 and two classes in year five with children aged 11 in a Swedish primary school. When the project started the pupils had been using the computers for about 2,5 years. In contrast to the teacher in grade five, the classes in year three had teachers with a great interest in developing ICT. The children became very skilled in using ICT and working with the laptop was very popular. According to the theoretical model of Voogt (2008), features of a "traditional pedagogy", like prescriptions of the activities, were mixed with elements of an "emerging pedagogy", where the pupils in collaboration performed their tasks in a creative way. However, some of the classroom work was quite unfocused relative to the goals of the subject. Instead of using the technology to reach the goals of the subject, the technology more or less became a goal in itself. To follow up ten Brummelhuis' and Kuiper's (2008) terms technology push and educational pull, we have added the term "technology pull."
\end{abstract}

Keywords: Teaching design; Computer use; Technology push; Technology pull; Primary school; One-to-one learning environment.

\section{Introduction}

As a consequence of the increased use of information and communication technology in general in society, the amount of computers has increased in the classrooms of Swedish schools. Statistics show a great variation between different schools; some of them have invested in a one-to-one laptop environment whilst others only have a few computers for the whole school to share (The Swedish National Agency for Education, 2010). When it comes to how the pupils learn to use the new technology, the access to computers is a critical factor (ten Brummelhuis \& Kuiper, 2008). Plenty of research has been done regarding computers in schools describing the technology of the computers and the skills required to operate them as well as how teachers and pupils experience using ICT both regarding Swedish conditions (Grönlund et al, 2011; Hallerström \& Tallvid, 2008; Hylén, 2010; Tallvid \& Hallerström, 2009) and international conditions (Ilomäki, 2008; Penuel et al 2001; Silvernail, 2004; Warschauer, 2006). 'What to do?' has been the dominant question, overshadowing the question of 'Why do it?' This article is focusing on ICT related to the pupils' learning; how that technology can be used in teaching to reach the educational goals. 


\section{Different Pedagogical Approaches}

The pedagogical approach of the teacher is correlated with how ICT is used in teaching. Teachers who believe their task is to transfer knowledge and skills from a given curriculum with a high degree of teacher control seem to avoid computers in their teaching. However, teachers who stimulate team work or individual work from the interest of the pupil seem to use ICT more often in their teaching (Riel \& Becker, 2008). From a historical point of view, we have chosen to highlight three perspectives of pedagogical approaches to teaching.

From a traditional perspective of teaching, the teacher is looked upon as an expert in knowledge the pupils have to learn. The pupils are passive receivers of knowledge and they are expected to reproduce the knowledge that they are taught. The pupils are assessed based on how much they remember of what they have learned. Knowledge is seen as a product as opposed to a learning approach pointing out the process. The traditional approach derives from the behaviorist theories of learning wherein a correct answer awards the pupil with praise whilst an incorrect answer results in a negative response (Skinner, 1950). From this perspective knowledge is an absolute, reflecting universal truths about reality. The assessment is focused on the product, the data and the predefined fragments of certain contents (Dede, 2008).

The behaviorists' view was followed by that of the cognitivists. Both approaches have in common that they see reality as impartial, but the latter focuses more on the symbolic and mental processes of the individual. The cognitivists' focus is on the psychology of learning. That means that the individual learns by being able to build knowledge based on the relationships between the content and the skills. The task of the teachers is to organize what is to be learned in order to facilitate the mental processes of learning. To obtain knowledge is a mental activity which requires that the individual is able to code and structure the information. Teaching therefore pays attention to cognitive skills and effective structures (Andersson, 1993; Bruner, 1960).

If the behaviorists and the cognitivists look at learning as a product, the theories of the constructionists look at learning as a process wherein individuals interpret and create personal pictures of reality from their knowledge and past experiences. In a constructionist approach, the interplay with others and the cultural dimension plays an important role, which has given name to the socio-cultural perspective (Ivarsson et al., 2009; Vygotsky, 1978). The role of the teacher is to support and motivate the pupils, to stimulate, give advice and provide them with tools for solving tasks. The responsibility of learning is put on the pupils and therefore they must be active and search for information. The teacher becomes a coordinator or a coach who is among the pupils and takes part in their questions, stimulating and supporting them on their individual level. The pupils are pushed to be independent, critical, and look for alternative solutions and test new ideas (Dede, 2008). If the emphasis of the traditional approaches is on the teachers, the constructionists' approach focuses on the pupils and on the activities they are doing in the process of learning.

When using ICT, and in order to develop the potential of what digital tools can offer, a new way of thinking is necessary; from knowledge transfer to knowledge construction, from exchange of information to transformative communication and from individual learning to a learning in an interactive and social context. The goal of ICT in this perspective is how to use it in teaching, how it promotes curiosity, cooperation and knowledge construction (Chan \& van 
Aalst, 2008). Figure 1 below shows how a "traditional pedagogy" differs from an "emerging pedagogy" (Voogt, 2008, p 121). The two types of pedagogies look at teaching from two different perspectives. In the traditional pedagogy we see similarities to the views of the behaviorists and the cognitivists while the emergent pedagogy shows similarities to the constructionists. Traditional pedagogy is teacher controlled, characterized by individual work, reproductive learning and emphasizes discipline. In an emerging pedagogy the pupils take a greater responsibility of their own work, the activities are determined by the learners, the pupils more often work in teams, the assignments are more problem based and the pupils are stimulated to find new solutions to problems. Further, there are more thematic and authentic works and the evaluation is more of a diagnostic character.

Figure 1. Overview of a "Traditional Pedagogy" and an "Emerging Pedagogy"

\begin{tabular}{|l|l|l|}
\hline Aspect & "Traditional pedagogy" & "Emerging pedagogy" \\
\hline Active & Activities prescribed by the teacher & Activities determined by the learners \\
& Whole class instruction & Small groups \\
& Little variation in activities & Many different activities \\
& Pace determined by the program & Pace determined by the learners \\
\hline Collaborative & Individual & Working in teams \\
& Homogenous groups & Heterogeneous groups \\
& Everyone for him/herself & Supporting each other \\
\hline Creative & Reproductive learning & Find new solutions to problems \\
& Apply known solutions to problems & Productive learning \\
\hline Integrative & No link between theory and practice & Integrating theory and practice \\
& Separate subjects & Relations between subjects \\
& Discipline-based & Thematic \\
& Individual teachers & Teams of teachers \\
\hline Evaluative & Teacher-directed & Student-directed \\
& Summative & Diagnostic \\
\hline
\end{tabular}

Source: (Voogt, 2008, p.121)

\section{Purpose}

The purpose of this article is to illustrate and discuss how pupils in year three and five in a Swedish primary school used laptops for their classroom work. Which pedagogical approach, a "traditional pedagogy" or an "emerging pedagogy" (Voogt, 2008), was the dominating one? Further, how was the teaching organized and what kind of activities did the pupils take part in?

\section{Material and Method}

The empirical material used in this study has been drawn from a research project funded by University West, Sweden. The pupils had been using laptops for about 2,5 years when the project was initiated in January of 2011. This article is based on findings from the first part of the study which was finished in June 2011.

The findings presented in this article were obtained mainly through classroom observations. In addition, some interview material was also used. The observations and interviews were, however, separated in time and space. Two classes in year three (history, writing and science) 
with 24 and 25 pupils respectively and two classes in year five (English) with 24 and 24 pupils respectively were studied along with their teachers in the classroom environment. The children in these years were 9 and 11 years old. During the spring term, the pupils in year three were observed on 17 occasions whereas the pupils in year five were observed on 10 occasions. One of the main advantages of observation is that the research objectives can be studied in their natural settings (Schulz-Zander, 2008), which in the present study means the classroom. During the observations, the themes in Voogt's (2008) model were in focus, namely the active, collaborative, creative, integrative and evaluative aspects of pedagogy. The classroom work observed thus concerned what type of activities the pupils and teacher engaged in and who defined the content and form of those activities. Further areas of interest were if they worked on their own or together with others and if the pupils were encouraged to be creators in their own learning process. The observations also concerned whether subjects or topics stood alone or were integrated in the activities, and, finally, whether the pupils and the teacher evaluated what had been learnt. The researchers tried, however, at all times to keep an open mind as to what was happening in order to gain an overall view and a more comprehensive understanding of the classroom activities. The authors would sit at the back of the classroom and observe while the teacher and pupils interacted, but when the activities allowed, the authors would also move around in the classroom. Field notes were taken which were typed up immediately afterwards together with reflections on information gained and questions raised. Photographs were also taken to document practices and activities. The observers did not remain detached during these lessons, but answered questions from the pupils and asked them about their work. This communication surrounded the activities the pupils were engaged in and its primary purpose was to contribute to a relaxed atmosphere, not add to the data.

Interviews were conducted with pupils and teachers. The interviews with the pupils were conducted with one interviewer (in grade three sometimes two interviewers) and the pupils in pairs to make them feel more comfortable and thus more likely to speak candidly. The risk of interviewing in pairs is that one person influences the other or that one person takes over, not letting the other person speak. However, as it was of utmost importance that the pupils felt secure and at ease with the situation, it was considered that having the safety of a classmate nearby would be beneficial to the outcome of the interview (cf Formosinho \& Araujo, 2006).

The interviews with the teachers were individual and in grade three sometimes in pairs. This was because the teacher in year five worked alone while the teachers in year three sometimes work together and sometimes apart. The interviews with the pupils and the teachers were held in a small room at the school and were audio-recorded. Interview guides were used for all interviews.

In addition to the formal interviews, there was continuous interaction between the researchers and the pupils and their teachers. The teacher also provided reflections and opinions after lessons.

There are benefits to using a combination of observations and interviews. Unstructured observations can pose a difficulty to the observer as they are unbiased and hence very broad in scope. However, by not having decided to look for something particular in advance, the observer is free to focus on whatever looks interesting, thus being able to discover unexpected events and patterns. Also, questions can arise during observations which deserve to be explored more in-depth in an interview. 
The researchers have a background in education and thus entered the classroom equipped with both pre-existing knowledge and pre-formed conceptions. The obvious advantage of being familiar with the setting is that it is not necessary to start from scratch. A disadvantage is that it is easier to over-interpret what is observed.

When openly observing and interviewing people there is a risk that those observed and interviewed show the researchers what they think they want to see. In this case, it could be that more technology use was shown deliberately to please and impress the observers. If the school staff value technology, that is what they are likely to want to emphasize.

\section{Classroom Work with Laptops in Year Three and Five}

Here we will present the classroom work of year three and five. Both years used Mac laptops. In year three the teachers were very keen on using the laptops and regularly introduced new applications for the pupils, while the teacher in year five introduced new programs more sparingly. A characteristic element in organizing the teaching of the year three classes were the mini lessons, a concept picked up from Lucy Calkin's New York Model (Calkins, 2010). The teacher usually started the lesson with a mini lesson; gathering the pupils to tell them what to do or explaining something. The mini lesson started in a corner of the classroom where half of the pupils were sitting on a sofa and the other half beneath on the floor. The corner was equipped with a projector and a document camera. When the pupils were to use a new application, the teacher first presented it in the mini lesson and then the pupils had to repeat it to each other in pairs before they returned to their desks and tested it on their own laptops.

During the spring term, the year three classes worked, among other things, with two themes for a longer period of time and a shorter one where the laptops were used in different ways. The first theme was about prehistoric times and lasted for 4-5 weeks. For this theme the teacher chose to concentrate on dinosaurs. The teachers gave the pupils some tasks to perform by using a couple of programs. The procedure looked like this:

1. Choose a dinosaur

2. Find facts about your dinosaur and write it in Mindnode

3. Write a script (with whole sentences) in Pages

4. Make a dialogue and record it in Garageband

5. Make a film in Icananimate

The italicized names are all programs for Mac computers. Mindnode is a program for organizing keywords. Pages is a word processing program, Garageband records speech and music and Icananimate is for creating animations.

The second theme/work area was called the author's workshop and went on from November 2010 to March 2011. The pupils wrote their own stories in the word processing program where they also were able to edit their texts. The third theme was a shorter one which only took a couple of lessons. The latter one was in science, a water experiment, and the pupils had to find out how many water drops they could put on a coin before it overflowed. In this case the pupils were supposed to make a film, record themselves in Photobooth while doing the experiment and edit it in iMovie.

As opposed to the mini lessons in year three, the observed English lessons in year five usually began with a teacher-led warm-up activity. This activity was most often linked to the content 
of the ensuing lesson. The teacher would typically stand in front of the whiteboard, facing the children in their seats. After this initial activity, the teacher would explain what the pupils were to work with in that particular lesson.

In the spring, the pupils in year five approached the subject of English during the lessons observed mainly through working with The Famous Person Project and working with their textbooks. They used their laptops for both activities, albeit in somewhat different ways. For The Famous Person Project the pupils were supposed to choose a celebrity and make a presentation about this person in English in the form of a slideshow. The pupils were not given a timeframe for the project, but it lasted 11 weeks, running in parallel with other lesson work. The teacher outlined what they needed to do on a large sheet of paper. According to that they were to;

1. Collect information

2. Write about the chosen person in Pages or Open Office

3. Make a presentation in Keynote or iMovie including power point, pictures, text and their own recorded voice.

Open Office is a program for word processing. Keynote and iMovie are both Mac programs, the first is used for making slideshow presentations and the second for making films.

The other activity was textbook work. The pupils usually did one chapter in the textbook per week. The textbook they used comes with a traditional paper workbook and a CD workbook. Tasks linked to textbook work would include reading texts, listening to texts together through the loudspeakers, writing exercises in their paper workbooks and listening, writing and speaking exercises in their CD workbook. The teacher wrote instructions for what the pupils were to do on the whiteboard. An example from 14 March:

You need;

- Workbook: Page 50-51

- Classbook: Chapter 14 "Mike's Lucky Day"

- The Magic CD chapter14 listen 2-3 times look at the pictures in classbook and retell the story

- The Mac + headset

\section{Discussion of Computer Use in Teaching}

As opposed to many other projects of one-to-one laptop programs, this project studied younger children between 9 and 11 years old. At these ages it is important to focus on basic knowledge and skills such as reading and writing. The question is how these abilities and skills are taught and what pedagogical approach is the dominating one when using the laptops. Have the teachers left the traditional pedagogy behind to use an emerging pedagogy, which according to Dede (2008) and Voogt (2008) encourages the pupil to be independent, think critically and to be a problem solver? 


\section{Pedagogy with Technological Devices in Focus}

The first of Voogt's aspects in Table 1 is about activities. In a traditional pedagogy the activities are prescribed by the teachers, it involves whole class-instruction, little variation in activities and the pace is determined by the program. In an emerging pedagogy, the activities are determined by the learners, involving small groups, many different activities and a pace determined by the learners. Referring to the empirical cases described above, we claim that the activities in this study mainly bear traces of a traditional pedagogy, but as we will see further on in the text there are also ingredients of an emerging pedagogy.

Both in year three and five the activities were planned in detail and decided by the teachers. In year three the assignments were mostly introduced and given to the pupils in the mini lessons. The pupils also saw the assignments in written form on the big whiteboard (whole-class instruction). Every task was formulated in a clear way so that the pupil knew what to do and what program to use. For example, when the pupils had decided what kind of dinosaur to study, they were supposed to find facts following a template, a specification of what is important to mention, what the animal looks like, its size, food, babies and other things. In the application Mindnode the pupils were supposed to write down the main points as a base for the next step, when they made a script, written in complete sentences, in the application Pages. That meant that different applications should be used for different activities and the final work should be presented in a prescribed way. All the pupils were supposed to do the assignments in the same way. Instead of writing and drawing in a traditional way the pupils were doing their assignments on the laptop. The pupils worked with the two first steps individually and they did the next three steps in pairs. Some pupils did it very quickly while others took their time. The collaborative work and the learner's decision of the pace of the work are indicating the quest for an emerging pedagogy.

Even though the teacher prescribed the activities of what to do, the pupils were given space for their own search and problem solving within the frame of the activity, eg. finding facts about the dinosaur on the internet. The teacher encouraged the pupils to search on the internet and she gave them a web address. Unfortunately they did not find that much about dinosaurs on this page. They tried to find other pages, but it was difficult to find a relevant one. Either the text was too difficult to understand, the language too advanced (e.g. Wikipedia), the text was in English or they came to web pages offering dinosaurs to buy in one form or another. The search was like trial and error and it was time consuming. When finding so many interesting hits on the web some pupils after a while seemed to have forgotten what they were looking for. Most of them ended up using books from the library, books the teacher had borrowed for the project. The teacher was during the lesson very busy helping the pupils. The evaluations of their work took place during the work process which ended up in the presentations of the animated films. In terms of Voogt (2008, fig. 1), we categorize this to be evidence of an emergent pedagogy which in its nature is student-directed and diagnostic, compared to the evaluative aspects of a traditional pedagogy which are teacher-directed and summative. As far as we could see, the teacher could only assess the classroom work and the films but not the pupils' individual knowledge of the dinosaurs.

The shortest activity, the water experiment, also showed a rather strict prescription by the teacher. In this case the pupils only got information about what kind of equipment to use and very briefly what to look for in the experiment. There was no introduction to science before the experiment, e.g. knowledge of physics the pupil could use to draw conclusions from based on what they had observed. Most of the interest was focused on the technology, what to do 
and how to record their experiment in Photobooth and iMovie. When the pupils in pairs presented the recorded film to the audience, the discussion mostly focused on the ways they had recorded the experiment and how they had used the applications.

The activities observed in the classroom in year five were also to a large extent teachercontrolled, following Voogt's description of a traditional pedagogy. The teacher would give them instructions both orally and in writing on the white board in the beginning of the lesson. The instructions always contained information on both the subject matter of the activity and the program or programs suitable. Whole class instruction was used. The form of presentation was also set by the teacher. Weston and Bain (2010) exemplify the lingering educational paradigm with precisely such non-differentiated large-group instruction. In The Famous Person Project the teacher told them what to do, both at the start-up of the project and in the beginning of every lesson, in which they were to work on the project. The teacher also told them that they could use Pages or Open Office while gathering facts and writing their manuscript. The end product, the slide show, was supposed to be presented in Keynote or iMovie. As opposed to the teachers in year three, the teacher in year five did not show the same inclinations to introduce an array of applications. Following the teacher's suggestion, the pupils above mainly worked with word processing and presentational programs.

While working on The Famous Person Project the pupils toiled on their own. It was supposed to be individual work and the pupils heeded the instructions. They did, however, collaborate over technological issues that needed solving, for example when one girl's text kept disappearing from her presentation she asked some other pupils for help. Interesting to note here is that talk about the technology was permissible in Swedish. Seeing as the pupils spoke quite a bit about technology, asking each other how to navigate the software or how to recover lost recordings, the Swedish language was used at the sacrifice of English.

When the pupils in year five were asked in the interviews what they mostly do with the computers during English lessons, 32 out of 47 replied working with textbook materials. The lessons observed during which they worked with the textbook and workbook followed very much the same pattern as described above; the teacher instructed them both orally and in writing of what to do and they then performed the various tasks requested. Sometimes they worked with the paper workbook and sometimes with the digital version, but both were quite traditional in their design and the focus was mainly on reproduction. Again they worked individually to a large extent. Sometimes they recited the text to each other and read dialogues in pairs, but the brunt of the work was done interacting with the screen rather than the classmates. A contributing factor to the individual work was probably that they were allowed to listen to Spotify as long as they had preselected playlists. Needless to say, interaction with one's classmates becomes inhibited when one has music coming through the headphones. An example of an exchange between two pupils working with their CD workbooks while listening to music through their headphones: "What did you write on number 4?" "Climb." "OK."

\section{The Technology as a Driving Force}

The pedagogy described above has illuminated traits from both a traditional and an emerging pedagogy, but what was even more obvious in the empirical cases was the emphasis on computer use and the different programs. In the observed classes we saw the technology as a driving force. Ten Brummelhuis and Kuiper (2008, p. 99) write about "technology push" and 
"educational pull". When a learning process is driven by technology without any specific need from the perspective of the educational goals or what is to be learned it is referred to as technology push. Technology push starts with the acquisition of ICT materials and then suitable applications are sought that fit into the learning process. If the learning process and the use of ICT materials are led by the demand or the need of the learning content, it is referred to as educational pull. In the perspective of technology push the risk is that the use of ICT becomes a goal in itself instead of being a medium which is supposed to enhance the learning process. When the teachers in year three introduced one application after another in the dinosaur project, how to use them became more important for the pupils than the knowing and the understanding of the subject to learn. From the perspective of educational pull we ask the question: How can the application support the pupil's learning process? To answer this question we also have to ask the question: Why is this learning process important or interesting and what is to be learned? For example, why are the dinosaurs interesting? What is to be learned in view of the goals of the theme? If the goals of the particular theme of knowledge go hand in hand with the technology, the focus on the learning process becomes clearer. The teaching in year three, and also in year five to a certain extent, emphasized the programs and the technology and in view of this we would like to introduce a new term, namely technology pull. Using the different applications and presenting them like a show was more important than focusing on the knowledge of the subject content. The interest of technology was at the forefront and the goals and the actual learning of the subject came second.

So far teaching strategies where mainly traits of a traditional pedagogy, as described by Voogt, have been illuminated. Using ICT has rather been a goal than a support for learning something. Not all themes were taught like this. We will now point to instances when the computer programs were a support in the learning process and the usage of ICT approached an educational pull.

\section{ICT Use with the Subject Content in Focus}

In the case of the author's workshop, signs of an emerging pedagogy developed. The activities were at least to some extent determined by the learners, the pupils worked in pairs and the pace was determined by the learners (cf Voogt, 2008). In the author's workshop the ICT worked as support in the learning process. Here we were able to connect the goal of the subject to the use of the different possibilities of the word processing program. The decision of the application was based on what the pupil was expected to learn. Hinostroza et al. (2008) point out the variations of ICT applications where different applications encourage different kinds of learning. The teacher therefore needs to ask the question: What application facilitates and stimulates learning in this specific situation? In the author's workshop the pupils developed their own texts according to ability and the pace was determined by the learners in cooperation with their writing mate. The pupils were continually taught writing rules. By returning to the pupil's own written text and editing it, the pupil could gradually improve the quality of the text. The different writing rules were about e.g. the introduction of the story or the finishing part, capitals, new paragraphs, quotes etc. After the pupils had revised their texts in the word processing program, the pupils in the writing-pair exchanged texts, read and were supposed to make comments on each other's texts. The pupils also regularly e-mailed the text to their teacher for feedback. The word processing program made it possible to work with the same text in many ways, change it, add text and edit without any visible corrections in the final text. The quality of the text was not even dependent on the pupil's handwriting. The look of 
the text on the computer was the same for everybody and in this sense it created equality among the pupils and even in relation to the teacher.

Although the author's workshop seemed to reach the image of an emerging pedagogy we observed some obstacles on the way. During the collaborative work, when the pupils in pairs were reading and criticizing each other's texts, they lost their concentration and started to chat about other things with each other. We do not have the answer of to how to remedy this, but it looked like they were so busy with their own texts that it was difficult to engage in another's.

Despite the fact that the description of the English lessons in year five thus far to a large extent indicates what Voogt (2008) denotes a traditional pedagogy, there was also evidence of what the same author calls an emerging pedagogy. In The Famous Person Project the pupils largely determined the scope of the activity. Some pupils chose to write a lot of text, others took a minimalistic approach. Some pupils focused on the pictures more than the text and showed great interest in picture editing. They also chose the pace of the activity. As no deadline had been given, they took the time they felt they needed. The first pupil presented his finished project after only two lessons. Most pupils presented their projects within the 11 week period the activity lasted, but, according to the teacher, at the end of spring term, there were still pupils who had not finished their projects.

Some of the activities they did in year five with the computer did not directly result in improved English skills. However, working with the computers provided the pupils with opportunities to develop other skills which would not have been that straightforward to develop without computers. They, for example, became better at searching for information on the internet, using various types of software for chosen purposes, designing slideshows and editing pictures. This in turn enabled them to make their Famous Person Projects unique and according to their own tastes, both regarding content and form, thus influencing their learning situation. Being able to work with something which seems relevant and you feel you can master as well as feeling in charge of one's own learning is important for motivation (Dörnyei, 2001).

If we look at the collaborative, creative and integrative aspects, as noted by Voogt (2008), of how the teachers and pupils in the observed classes used ICT, we also found traits of an emerging pedagogy.

\section{ICT Lays the Foundation for an Emerging Pedagogy}

Creative aspects representative of an emerging pedagogy are characterized by productive learning and finding new solutions to problems. Collaborative aspects represented from the same perspective are working in teams, heterogeneous groups and supporting each other. The integrative aspects are characterized by integrating theory and practice, relations between subjects and themes and teams of teachers (Voogt, 2008). When it comes to the aspects of creativity in year three, the teachers' quite detailed instructions gave a first impression of a fairly controlled type of teaching. However, when observing the pupils, what they did, how they did it and with whom they did it, the image of the process changed. The different applications opened up for trying and practicing different skills. Further, the applications enabled the pupils to express and present their work in a multifaceted way, which showed a variety of solutions and productive learning. 
When it comes to their ways of working, to the collaborative work, we can see them approaching an emerging pedagogy. An example of this is the writing mate in year three who they changed twice a term. They were doing a couple of assignments together with their writing mate on a daily basis. For example, in the work with the dinosaurs there were a couple of tasks the pupils did in pairs, from writing a script to making the setting and recording the animated film. In the same way the pupils worked in pairs in the water experiment and the author's workshop. In the interviews with the pupils, nearly everybody expressed pleasure about working with their writing mates. Even outside the writing pairs we saw the pupils helping each other and giving hints when somebody had problems or sometimes just to tell the other pupil about a new application. The collaboration not only strengthened the social relationships among the pupils, it also increased the learning of the subject and the ICT. The integrative aspects, team work and thematic work, were particularly obvious in year three. As a consequence of teaching the classes in all subjects, it was easy for the teachers to mix them in a thematic way. The two teachers in year three had a fixed meeting time once a week when they planned the work together. In addition, they met every now and then on a daily basis, as they had classrooms next to each other.

Earlier in the article we saw the technology as a driving force in the teaching. The technology was in the foreground and sometimes it was not easy to detect the goals of the teaching. From a perspective of learning a subject, such an imbalance can be a drawback. However, during the three years the pupils have had the laptops they have gradually built up knowledge and security in dealing with the technological devices, a competence which they were proud of. Using the laptops for school work was very popular. When the teacher asked the pupils to take out the laptops we could hear a - Yeeees! A sound of happiness. When we walked among the pupils in the classroom as observers they were often very keen on showing us what they had done on their laptops. We asked the teachers in year three in the interviews how they motivated the pupils. They answered that working with the laptops influenced the pupils' motivation greatly. The pupils' positive attitudes were probably linked to their daily habits of using computers both at home and in school; they had practiced using many applications so they were quite skilled. The teachers in year three showed great interest in using ICT for school work and they encouraged the pupils to learn as many applications as possible. Knezek and Christensen (2008) consider the attitudes and the engagement of the teacher to be a precondition for a successful implementation of ICT-usage. They explain that the ICT-promoted attitudes of the teacher are passed on to the pupils. A related study on 1:1 laptop computing for older pupils (Kengwee et al., 2012) confirms a positive impact on pupils' engagement and learning.

The computer certainly gave the pupils in year five new opportunities in terms of creativity. According to Voogt (2008), finding new solutions to problems and productive learning denote an emerging pedagogy creativity-wise. Through the work with the slide show the pupils could explore new ways of finding information, designing the slides and presenting their end product. Most of the pupils also said in the interviews that they had enjoyed working with the famous person project, something which can be assumed to have functioned as a motivating factor (cf Bebell \& O'Dwyer, 2010; Dörnyei, 2002; Dörnyei et al., 2006). The teacher said that she felt the pupils enjoyed working with The Famous Person Project because of the extensive computer use. She explained it as "the means justifying the end".

The pupils often encountered technical difficulties in their work. There was never any technical support available at the school when these problems occurred which shows that the teacher 
and pupils were supposed to be able to sort things out by themselves. As the teacher confessed to not being more knowledgeable than average, much responsibility was put on the pupils to fix their own technical difficulties. This follows Prensky's (2001) reasoning regarding young people being digital natives and being at home in a digital environment. This is however a simplification. The pupils in year five were not necessarily skilled in computer problemsolving, they knew things related to how they used the computer out of school. That meant that they, for example, were experts on how to get the most out of Facebook, where to find the nicest pictures or how to proceed to the next level in the latest game, but not that they were experts on word processing or the functionalities of Mac software.

In contrast to what has been observed regarding collaborative work in year three in this study and what Warschauer (2008) observed in his study of computer use in American schools, the pupils in year five mainly did individual work. All the different work segments in the Famous person project and most of the textbook work were performed individually. However, this does not mean that the pupils and their teacher did not find new ways of working. The pupils explored new programs and modalities and experimented with recordings and picture quilting, mostly by themselves without the teacher being involved. In fact, no explicit instruction concerning the programs was observed. What is more, they also often found new learning paths. The teacher was not the absolute authority regarding computer software; pupil experts emerged to whom pupils and teacher in need turned to. One pupil in particular was very deft with Apple software and would be asked for help on numerous occasions. At our first meeting he proclaimed, not without pride: "You should study me because I'm the pro!" The downside of this proficiency was that he sometimes felt that he had to leave the classroom to get any work done.

\section{Conclusion}

Constructivists look at learning as a process where the learner constructs new knowledge and understanding through active participation. From this view, learning environments are created which allow for authentic learning and learner-centered education. Voogt (2008) has formulated the characteristics of a traditional pedagogy and an emerging pedagogy (fig. 1) which have been used for the analysis in this study. From the present studies we have pointed out traits of a traditional pedagogy but also mentioned traits of an emerging pedagogy.

\section{A Quest for an "Emergent Pedagogy"}

The activities referred to in the text were largely teacher-controlled. An explanation can be that the pupils of the observed classes in year three and five in primary school are quite young, and that at these ages the pupils still work on basic skills in eg. reading, writing and building up ways to work. Also, younger children are less autonomous and have more need for regular, individual and personal feedback than older pupils. When the teachers in year three described the activities in detail, in different ways, they probably did so to correspond to the needs of the pupils' age level.

Constructing a learning environment according to an emergent pedagogy also means to emphasize collaborative, creative, integrative and evaluative aspects of work. "ICTs do not change pedagogic practices themselves" (Somekh, 2008, p. 452). Rather, teachers can change them, in collaboration with their pupils. Compared to the pupils in year five, the pupils in year 
three worked quite a lot in pairs. The assignments were most of the time constructed to stimulate collaborative work. Within the framework of making stories, reading dialogues, recording speaker texts and producing films the pupils used a lot of applications and had great opportunities to develop their creativity. The integrative aspect was present in their thematic work although it could have been more visible if the teaching had included more subjects. The evaluative aspect in grade three was mostly prominent in the pupils' work processes and in their performances presenting their work in front of the class. However, there was not a clear connection between the goals of the subject and the presentations. Rather, it looked like the presentation was a goal in itself. In year five the pupils mostly worked individually and they had one teacher per subject, thus staying in the field of traditional pedagogy regarding the collaborative and integrative aspect. However, regarding the creative aspect, they explored a variety of applications which enabled them to find new solutions to problems. This was especially evident when they worked with the Famous Person Project in which they made a slide presentation, working with both pictures and text as well as recordings of their own voices. The evaluative aspect was visible during the studied period mainly through studentdirected feedback of the work they were doing with the textbook materials and the Famous Person Project. Both the creative and the evaluative aspects of the work in year five were therefore closer to an emerging pedagogy. However, just as we experienced regarding the evaluative aspect in grade three, it did not become clear to us which were the goals of the Famous Person Project and consequently what there was to evaluate.

Voogt's model for analyzing teaching is useful as a starting tool for paying attention to various aspects of teaching. It is, however, also associated with some deficiencies. First of all the concepts of traditional pedagogy and emergent pedagogy are connotations. Teachers possess vocational pride and want to be modern, and therefore it is easy to instinctively associate traditional with something bad and emergent with something good. In our studies we have seen that using a traditional pedagogy can sometimes be relevant for younger pupils. Children in primary school often need more detailed instruction and feedback to build up their skills, but also for their personal and social comfort. We also conclude that using an emergent pedagogy not always improves learning of the subject if the teaching is more focused on the technological issues and less on the goals of the subject. From this perspective one more aspect should be added to Voogt's model, an aspect emphasizing the teachers' and pupils' consciousness of the goals in the syllabus when working on a project.

\section{Technology Pull Instead of Educational Pull}

Ten Brummelhuis and Kuiper (2008) speak of educational pull and technology push. If teachers and pupils feel the need for using technology in order to enhance learning, the implementation of technology is a result of educational pull. If technology is bought and the teachers and pupils are told to use it, they experience technology push. The latter does not make for very successful introduction of ICT in schools (ten Brummelhuis \& Kuiper, 2008). In the present study, we presented the new term technology pull, which implies a quest for new technology, seeing it as something stimulating and interesting to work with. The teachers in year three were clearly very interested in using computers in their teaching from the beginning. In their enthusiasm for different kinds of applications they rather let the technology become a goal than asking what it was good for. As a contrast, the teacher in year five was more hesitant. While she believed the computers opened up fantastic opportunities, she also expressed concerns regarding what she now had to take away from her teaching in order to fit 
in the new approach. "I don't think it [the computer] should be used too much." Symptomatic of this view is that this teacher also decided to work with writing by hand in English the following term.

In terms of technology pull we can see both benefits and risks. In general, the pupils very much liked using the laptops. ITC motivated them to be active in their schoolwork and they even learnt things outside the curriculum, experiencing authentic learning. Motivation is an important factor for the performance capacity of a pupil (Holden, 2001) and in this light it can be a benefit to focus on things which the pupils find enjoyable. When the teachers focus on the technology too much there is a risk that the pupils do not concentrate enough on the subject goals which can be a problem for their performance further on. We know from research that technical devices like laptops do not always have a positive impact on the pupils' achievement (Warschauer, 2008). Machin et al. (2006) conclude, from a number of investigations across different school districts in England, that ICT in primary school has a positive impact on English and science, though not on mathematics. In order to move from the technology pull evident in the present study to an educational pull, the teachers in both year three and five need to put more emphasis on the content and the syllabus goals. Ten Brummelhuis and Kuiper (2008) find that the starting point is setting clear targets and instructional goals for the pupils' learning. As far as we can see, a more clearly goal-oriented and syllabus-based learning environment would benefit and enhance the work the teacher and pupils do with the computers. For this process ten Brummelhuis and Kuiper (2008) propose addressing four questions: What do you want to learn? Where are you now? How can you get there? and How do we test what we have learned? Guided by these questions the pedagogical use of laptops in both year three and year five could be further explored and developed and the teachers and pupils could move even closer to making theirs an emerging pedagogy.

\section{References}

Ainley, J., Enger, L., \& Searle, D. (2008). Students in a digital age: Implications of ICT for teaching and learning. In J. Voogt \& G. Knezek (Eds.), International handbook of information technology in primary and secondary education. New York: Springer.

Andersson, J. R. (1993). Rules of the mind. Hillsdale, NJ: Lawrence Erlbaum Associates.

Bebell, D. \& O'Dwyer, L. (2010). Educational outcomes and research from 1:1 computing settings. Journal of Technology, Learning, and Assessment, 9 (1). Retrieved on 15 September 2011 from http://www.jtla.org.

Dede, C. (2008). Theoretical perspective influencing the use of information technology in teaching and learning. In J. Voogt and G. Knezek (Eds.), International handbook of information technology in primary and secondary education. New York: Springer.

Dornyei, Z. (2001). Teaching and researching motivation. Upper saddle, NJ: Pearson Education.

Dornyei, Z. (2002). The motivational basis of language learning tasks. In P. Robinson (Ed.), Individual differences and instructed language learning. Amsterdam: John Benjamins Publishing Company.

Dornyei, Z., Csizér, K., \& Németh, N. (2006). Motivation, language attitudes and globalisation. A Hungarian perspective. Clevedon: Multilingual Matters Ltd. 
Formosinho, J. \& Araújo, S.B. (2006). Listening to children as a way to reconstruct knowledge about children: Some methodological implications. European Early Childhood Education Research Journal, 14(1), 21-31.

Gronlund, H., Englund, T., Andersson, A., Wiklund, M., Norén, I., \& Hatakka, M. (2011). Årsrapport Unosuno 2011 vuxenutbildning [Annual report Unosuno 2011]. Örebro University. Retrieved on 19 May 2012 from http://www.hyperfinder.se/wpcontent/ uploads/2012/05/arsrapport_unosuno_2011.pdf.

Hallerstrom, H. \& Tallvid, M. (2008). En egen dator som redskap för lärande. Utvärdering av projektet "En-till-En" $i$ två grundskolor i Falkenbergs kommun - Delrapport 1. [You own computer as a tool for learning. Evaluation of the project "One-to-one" in two comprehensive schools in Falkenberg municipality- Partial report 1]. Research Report in Sociology of Law. 2008-9. Lund university.

Hinostroza, E. J. (2008). Traditional and emerging IT applications for learning. In J. Voogt and G. Knezek (Eds.), International handbook of information technology in primary and secondary education. New York: Springer.

Holden, I. M. (2001). Matematik blir rolig. [Mathematics becomes fun]. In B. Grevholm (Ed.), Matematikdidaktik, ett nordiskt perspektiv. Lund: Studentlitteratur.

Hylen, J. (2010). Digitalisering av skolan. [The digitalization of schools]. Lund: Studentlitteratur.

Ilomaki, L. (2008). The effects of ICT on school: Teachers' and students' perspectives. University of Turku. Retrieved on 28 May 2012 from http://www.doria.fi/bitstream/handle/10024/ 42311/B314.pdf.

Ivarsson, J., Linderoth, J., \& Saljo, R. (2009). Representations in practices: A sociocultural approach to multimodality. In C. Jewitt (Ed.), Handbook of multimodal analysis (pp. 201212). London: Routledge.

Kengwee, J., Schnellert, G., \& Mills, C. (2012). Laptop initiative: Impact on instructional technology integration and student learning. Education and Information Technologies, 17, 137-146. Retrieved on 25 May 2012 from http://www.springerlink.com/content/ x5r7725442520417/fulltext.pdf.

Machin, S., McNally, S., \& Solva, O. (2006). New technology in schools: Is there a payoff? Internationell forskningsöversikt kring IT I skolan. Stockholm Myndigheten för skolutveckling. Retrieved on 29 May 2012 from http://www.itochutbildning.se/wpcontent/uploads/2009/11/Internationell- forsknings\%C3\%B6versikt-av-IT-i-skolanslutlig-version.pdf.

Penuel, W. R., Kim, D. Y., Michalchik, V., Lewis, S., Means, B., \& Murphy, B. (2001). Using technology to enhance connections between home and school: A research synthesis. Menlo Park, CA: SRI International.

Prensky, M. (2001) Digital game-based learning. New York: McGraw-Hill.

Riel, M. \& Becker, H. J. (2008). Characteristics of teacher leaders for information and communication technology. In J. Voogt and G. Knezek (Eds.), International handbook of information technology in primary and secondary education. New York: Springer.

Schulz-Zander, R., Pfeifer, M., \& Voss, A. (2008). Observation measures for determining attitudes and competencies toward technology. . In J. Voogt and G. Knezek(Eds.), International handbook of information technology in primary and secondary education. New York: Springer. 
Silvernail, L. (2004). The impact of Maine's one-to-one laptop programme on middle school teachers and students. Maine Education Policy Research Institute, University of Southern Maine Office.

Skinner B.F. (1950). Are theories of learning necessary? Psychological Review, 57, 193-216.

Somekh, B. (2008). Factors affecting teachers' pedagogical adoption of ICT. In J. Voogt, J. and J. Knezek (Eds.), International handbook of information technology in primary and secondary education. New York: Springer.

Tallvid, M., \& Hallerstrom, H. (2009). En egen dator i skolarbetet - redskap för lärande? Utvärdering av projektet en-till-en i två grundskolor i Falkenberg kommun. Delrapport 2. [Your own computer for school work, a tool for learning? Evaluation of the project "Oneto-one" in two comprehensive schools in Falkenberg municipality. Partial report 2.] Falkenberg: Falkenberg Municipality.

ten Brummelhuis, A. \& Kuiper, E. (2008). Driving forces for ICT in learning. In J. Voogt and G. Knezek (Eds.), International handbook of information technology in primary and secondary education. New York: Springer.

The Swedish National Agency for Education (2009). Redovisning av uppdrag om uppföljning av IT-användning och IT-kompetens i förskola, grundskola och vuxenutbildning [Account of commission to monitor IT use and IT competency in pre-school, comprehensive school and adult education]. Reg.no. 75-2007:3775. Stockholm: Ministry of Education and Research.

Voogt, J. (2008). IT and Curriculum Processes: Dilemmas and Challenges. In J. Voogt and G. Knezek (Eds.), International Handbook of Information Technology in Primary and Secondary Education. New York : Springer.

Warschauer, M. (2008). Laptops and literacy: A multi-site case study. Pedagogies: An International Journal, 3, 52-67.

Weston, M. \& Bain, A. (2010). The end of techno-critique: The naked truth about 1:1 laptop initiatives and educational change. Journal of Technology, Learning, and Assessment, 9(6). Retrieved on 5 September 2011 from http://www.jtla.org.

Correspondence: Ann-Louise Petersen, Ph.D., Department of Educational Science and Languages, University West, Trollhattan, Sweden 